\title{
Anti-inflammatory effects of ivy leaves dry extract: influence on transcriptional activity of NFKB
}

\author{
Janka Schulte-Michels ${ }^{1} \cdot$ Christina Keksel $^{1} \cdot$ Hanns Häberlein $^{1} \cdot$ Sebastian Franken $^{1}$ (D
}

Received: 31 January 2018 / Accepted: 2 May 2018 / Published online: 11 May 2018

(c) The Author(s) 2018

\begin{abstract}
EA $575^{\circledR}$ is an ivy leaves dry extract (DER 5-7.5:1, 30\% ethanol) used against diseases of the lower respiratory tract associated with productive cough. EA $575^{\circledR}$ improves symptoms associated with chronic inflammatory bronchial conditions. Compared to its bronchospasmolytic and secretolytic properties, the anti-inflammatory effects of EA $575^{\circledR}$ are mostly untried. Therefore, we addressed the question of whether the anti-inflammatory effect of EA $575^{\circledR}$ is due to an impact on the $\mathrm{NF} \kappa \mathrm{B}$ pathway. NFKB nuclear translocation was visualized by immunofluorescence in J774.2 as well as HEK293 cells. In the latter, a luciferase-based reporter was used to monitor NFkB transcriptional activity. Phosphorylation of RelA and its inhibitor IкB

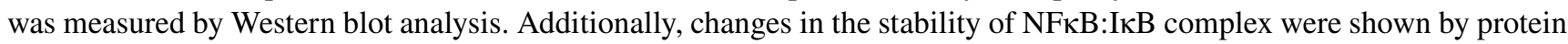
fragment complementation. Decreased transcriptional activity of NFkB under treatment with EA $575^{\circledR}$ was also shown for a human monocytic as well as a human lung epithelial cell line. EA $575^{\circledR}$ is able to inhibit NFkB transcriptional activity by partially inhibiting its translocation to the nucleus after stimulation with TNF $\alpha$. Furthermore, phosphorylation of I $\mathrm{B} \alpha$ is reduced while phosphorylation of RelA is enhanced after pre-incubation with EA $575^{\circledR}$, leading to an enhanced stability of

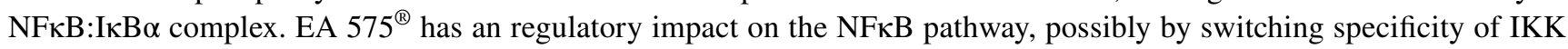
from $\mathrm{I} \kappa \mathrm{B} \alpha$ to RelA, resulting in enhanced stability of $\mathrm{NF \kappa B}: \mathrm{I} \kappa \mathrm{B} \alpha$ complex and reduced RelA translocation into the nucleus.
\end{abstract}

Keywords NFאB $\cdot$ Hedera helix $\cdot \beta_{2}$-Adrenergic receptor $\cdot$ Airway inflammation $\cdot$ EA $575^{\circledR}$

\section{Introduction}

EA $575^{\circledR}$ is an ivy leaves dry extract (DER 5-7.5:1, 30\% ethanol) used for the improvement of symptoms associated with chronic inflammatory bronchial conditions and acute respiratory tract inflammation accompanied by coughing. Its bronchospasmolytic and secretolytic effects have been proven in clinical studies (Lang et al. 2015). The mechanism of action is based on increased $\beta_{2}$-adrenergic responsiveness of the respiratory tract mediated by inhibition of GRK2mediated phosphorylation of activated $\beta_{2}$-adrenergic receptors, resulting in decreased internalization of $\beta_{2}$-adrenergic receptors under stimulating conditions (Sieben et al. 2009; Schulte-Michels et al. 2016b). The anti-inflammatory effect of EA $575^{\circledR}$ is less examined. As we have shown previously,

Sebastian Franken

sfranken@uni-bonn.de

1 Institute of Biochemistry and Molecular Biology, Rheinische Friedrich-Wilhelms-University, Nussallee 11, 53115 Bonn, Germany
EA $575^{\circledR}$ is able to reduce LPS-induced IL-6 release from murine macrophages (J774.2) (Schulte-Michels et al. 2016a). Besides the findings from cell culture experiments, there is also growing evidence from animal models regarding the anti-inflammatory effect of constituents of hedera helix leaves. Rutin and chlorogenic acid reduce the carrageenan-induced paw edema in rats (Selloum et al. 2003; dos Santos et al. 2006). Rutin also inhibits acute as well as chronic arthritis states in rats (Guardia et al. 2001). Through a mouse model of ovalbumin-induced allergic asthma, it was demonstrated that chlorogenic acid reduces the synthesis of IgE and Th2-cell specific cytokines like IL-4 and IL-5 (Kim et al. 2010). Additionally, chlorogenic acid protects mice against LPS-induced lung injury (Zhang et al. 2010).

Hocaoglu et al. (2012) demonstrated that an ivy leaves dry extract showed anti-inflammatory properties in a chronic-induced asthma model in mice (Hocaoglu et al. 2012). Compared to placebo, goblet cell count was significantly lower and basal membrane thickness was reduced in lung histopathologic studies when mice were treated orally with the ivy leaves dry extract. Süleyman and coworkers also 
found an anti-inflammatory effect for an ivy extract enriched with saponins in cotton pellet and carrageenan-induced acute and chronic inflammation in rats (Süleyman et al. 2003).

An important aspect of nearly all inflammatory processes is the transcription factor NFKB. Under non-stimulating conditions, NFKB is kept inactive in the cytosol by complexation with its inhibitor IкB $\alpha$. Stimulation of, e.g., macrophages with TNF $\alpha$ or LPS activates the IкB kinase (IKK), which in turn phosphorylates I $\mathrm{K} \boldsymbol{\alpha} \alpha$, resulting in a cleavage

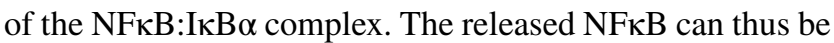
translocated into the nucleus, where it induces the transcription of different cytokines (Hayden and Ghosh 2012). Due to its relevance to inflammatory processes, we questioned if the reduced IL- 6 release from EA $575^{\circledR}$ pre-treated murine macrophages could be caused by an impact on the NFKB pathway.

In this work, we describe the influence of EA $575^{\circledR}$ on the transcriptional activity of NFkB in different epithelial and immune system-derived cell lines using a Nanoluc reporter cell system. The nuclear translocation of NFkB after TNF $\alpha-$ stimulation is examined by immunofluorescence microscopy; the phosphorylation of I $\mathrm{KB} \alpha$ and the stability of the $\mathrm{NF \kappa B}: \mathrm{I} \kappa \mathrm{B} \alpha$ complex is investigated using Western blots and a protein fragment complementation assay, respectively. We aim to elucidate the anti-inflammatory mode of action of ivy leaves dry extract EA $5755^{\circledR}$, and to further understand its beneficial effect on chronic inflammatory bronchial conditions.

\section{Materials and methods}

\section{Chemicals}

Nano-Glo ${ }^{\circledR}$ Luciferase Assay was obtained from Promega (Promega GmbH, Mannheim). Ivy leaves dry extract EA $575^{\circledR}$ (CID-100048) was obtained from Engelhard (Engelhard Arzneimittel GmbH \& Co. KG Niederdorfelden).

The reference substances rutin, hederacoside $\mathrm{C}$, hederacoside D, and $\alpha$-hederin were obtained from Phytolab (Vestenbergsgreuth, Germany).

All other reagents were obtained from Merck (Darmstadt, Germany), if not stated otherwise.

\section{Characterization of EA $575^{\circ}$ by HPLC analysis}

Ivy leaves dry extract EA $575^{\circledR}$ (DER 5-7.5:1, 30\% ethanol) (Batch number CID-100048) was obtained from Engelhard Arzneimittel GmbH \& Co. KG (Niederdorfelden, Germany). Chemical composition and pharmacological properties of relevant ingredients have been reported previously (Sieben et al. 2009; Greunke et al. 2015; Schulte-Michels et al. 2016 a, b). For further characterization, EA $575^{\circledR}$ was dissolved in $50 \% \mathrm{EtOH}$ in a concentration of $40.8 \mathrm{mg} / \mathrm{ml}$. EA
$575^{\circledR}$ was analyzed on a Agilent Series 1200 HPLC system equipped with a degasser (G1322A), a quaternary pump (G1311A), an autosampler (G1329A) and a photodiode array detector (G1315D) using a LiChrospher RP-18 column $(5 \mu \mathrm{m}, 125 \times 4 \mathrm{~mm}$, Merck, Darmstadt). Solvent A was $\mathrm{H}_{2} \mathrm{O} /$ acetonitrile $(44 / 2, \mathrm{~m} / \mathrm{m})$ adjusted to $\mathrm{pH} 2.0$ with phosphoric acid $85 \%$. Solvent $\mathrm{B}$ was acetonitrile. The following linear gradient was used: $0-9 \min 0 \% \mathrm{~B}, 9-10 \min$ to $6 \% \mathrm{~B}$, $10-25 \mathrm{~min}$ to $15 \% \mathrm{~B}, 25-50 \mathrm{~min}$ to $60 \% \mathrm{~B}, 50-51 \mathrm{~min}$ to $100 \%$ B, 51-65 min $100 \%$ B. Flow rate: $0-50,51-65$ min $1.5 \mathrm{ml} / \mathrm{min}$. Detection: $205 \mathrm{~nm}$. Identification of constituents was carried out by comparison of UV spectra of reference substances and their corresponding retention times. Chromatograms were registered and evaluated using Agilent Chemstation Software Version B.04.01.

\section{Cell culture}

The mouse macrophage cell line $\mathrm{J} 774.2$ was obtained from Sigma-Aldrich (Cat. Nr.: 85011428). J774.2 cells were cultured in DMEM without phenol red (Life Technologies, Carlsbad, CA) supplemented with 100 units/ml penicillin, $100 \mu \mathrm{g} / \mathrm{ml}$ streptomycin, $2 \mathrm{mM}$ L-Glutamin (Life Technologies) and 10\% fetal calf serum (Life Technologies). Cells were maintained by ten-fold dilutions with fresh medium every $2-3$ days.

Human embryonic kidney cells (HEK 293) obtained from DSMZ (No. ACC 305) (Braunschweig, Germany) were cultivated in DMEM medium (Life Technologies, Carlsbad, CA) supplemented with 100 units $/ \mathrm{ml}$ penicillin, $100 \mu \mathrm{g} / \mathrm{ml}$ streptomycin, and $10 \%$ fetal calf serum. Cells were maintained by threefold dilutions with fresh medium every 2-3 days.

Acute monocytic leukemia cells (THP-1) were obtained from DSMZ (No. ACC 16) and maintained in RPMI medium supplemented with $10 \%$ fetal calf serum, 100 units $/ \mathrm{ml}$ penicillin, $100 \mu \mathrm{g} / \mathrm{ml}$ streptomycin, $50 \mu \mathrm{M} \beta$-mercaptoethanol and $5 \mathrm{ml}$ Glutamax 100× (Life Technologies GmbH, Darmstadt). THP-1 cells were maintained by three-fold dilutions with fresh medium every $2-3$ days.

Human lung epithelium-derived cells (A549) obtained from DSMZ (No. ACC 107) were cultivated in DMEM/F12 medium (Life Technologies, Carlsbad, CA) supplemented with 100 units $/ \mathrm{ml}$ penicillin, $100 \mu \mathrm{g} / \mathrm{ml}$ streptomycin, and $10 \%$ fetal calf serum. Cells were maintained by three-fold dilutions with fresh medium every $2-3$ days.

\section{Immunofluorescence}

J774.2 or HEK293 cells were seeded on poly-D-lysine (PDL) coated coverslips in a density of 100,000 cells per well. At a cell density of $90 \%$ medium was changed to serum- and antibiotic-free medium. J774.2 cells were incubated with 
$80 \mu \mathrm{g} / \mathrm{ml}$ EA $575^{\circledR}$ HEK293 cells with $240 \mu \mathrm{g} / \mathrm{ml}$ EA $575^{\circledR}$ overnight. Serum-free medium served as a control. The next morning $100 \mathrm{ng} / \mathrm{ml}$ LPS and $25 \mathrm{ng} / \mathrm{ml} \mathrm{TNF} \alpha$ were added to J774.2 cells and HEK293 cells, respectively, and incubation was continued for another $50 \mathrm{~min}$. Afterwards cells were fixed with $4 \%$ formaldehyde in PBS, permeabilized with ice-cold methanol and blocked with 5\% BSA in PBS supplemented with $0.3 \%$ Triton X-100. Immunostaining was performed with RelA antibody (cell signaling technology, \#6956) in a dilution of 1:800 overnight and a Cy3 coupled secondary antibody in a dilution of 1:400 for $1.5 \mathrm{~h}$ in the dark. Additionally, cells were incubated with Hoechst 33528 for nuclear staining. Images were taken on a Zeiss Axiovert $200 \mathrm{M}$ with an LCI Plan-Neofluar 63×/1.30 Imm Korr Ph 3 M27 objective and an AxioCamMR.

\section{Generation of plasmids for protein fragment complementation}

Generation of protein fragment complementation plasmids, pCDNAHygr_cVenus-RelA and pCDNA zeo_IкBa-nVenus, was already described elsewhere (Yu et al. 2003) and was constructed by GeneArt (Thermo Fisher), according to the mentioned publication.

\section{Generation of NFKB Reporter Plasmid}

For the generation of a Nanoluciferase expression construct under control of NFKB binding sequence the pNF-KBD2EGFP vector (Clontech) was used as a template. Destabilized GFP was removed from the vector by PCR introducing a new XhoI-site (forward primer: 5'TCGGATATCTCGAGC CGGAATTCGGGGAAGCTTC-3'; reverse primer: 5'-GTT CAGGGGGAGGTGTG-3'). The open reading frame coding for destabilized Nanoluciferase was cut from pNL1.2[NlucP] vector (Promega) using BamHI/XhoI and introduced into the pNF-KB vector using the same restriction sites.

\section{Transfection}

HEK 293 cells were transfected by calcium phosphate method. Briefly, cells were seeded in 12 well plates and allowed to attach for at least $24 \mathrm{~h}$. Before transfection medium was changed to $900 \mu \mathrm{l}$ fresh medium. One $\mu \mathrm{g}$ DNA was mixed with $6.5 \mu \mathrm{l} 2 \mathrm{M} \mathrm{CaCl}_{2}$ and $50 \mu \mathrm{l}$ sterile water. The dilution was added dropwise to $2 \times$ HBS and after half an hour of resting added to the cells. After $24 \mathrm{~h}$, medium was changed to fresh DMEM containing antibiotic for selection (750 $\mu \mathrm{g} / \mathrm{ml}$ geneticin).

THP-1 cells were transfected by Amaxa electroporation technology, Nucleofector ${ }^{\circledR}$ II. For each transfection $2 \times 10^{6}$ cells were diluted in a self-made appropriate buffer $(5 \mathrm{mM}$ $\mathrm{KCl}, 15 \mathrm{mM} \mathrm{MgCl}{ }_{2}, 15 \mathrm{mM}$ HEPES, $150 \mathrm{mM} \mathrm{Na} \mathrm{HPO}_{2} /$
$\left.\mathrm{NaH}_{2} \mathrm{PO} 4 \mathrm{pH} 7.2,50 \mathrm{mM} \mathrm{NaCl}\right)$ with $1 \mu \mathrm{g}$ DNA and transfected with program T-020. Afterwards, they were transferred to fresh fully supplemented RPMI medium. Twentyfour hours later, medium was changed to full medium containing $700 \mu \mathrm{g} / \mathrm{ml}$ geneticin for selection with medium changes every 2-3 days. After 1 week of selection, surviving cells were tested for expression of the transgene.

A549 cells were transfected using branched polyethylenimine (PEI, \# 408727, Sigma-Aldrich, Darmstadt, Germany). Therefore, 50,000 cells were seeded into the cavities of a 12-well plate. $2 \mu \mathrm{g}$ of DNA was diluted into $40 \mu \mathrm{l}$ of $150 \mathrm{mM} \mathrm{NaCl}$ and $3.3 \mu \mathrm{l}$ of a $1 \mathrm{mg} / \mathrm{ml}$ PEI solution was added and the mixture was immediately vortexed for $10 \mathrm{~s}$. After $10 \mathrm{~min}$ at RT, the DNA/PEI mixture was applied dropwise to the cells and incubated overnight. The next day medium was changed to fresh DMEM/F12 containing antibiotic for selection $(500 \mu \mathrm{g} / \mathrm{ml}$ geneticin $)$.

\section{Measurement of NFKB activation through a Nanoluciferase-based reporter system}

Nanoluciferase expressing cells were seeded in 96-well LumiNunc $^{\mathrm{TM}}$ plates and were allowed to grow for $24 \mathrm{~h}$. Medium was changed to serum-free medium before incubation. Incubation with EA $575^{\circledR}$ was performed with indicated concentrations of EA $575^{\circledR}$ for $8 \mathrm{~h}$, respectively. After $5 \mathrm{~h}$ indicated concentrations of TNF $\alpha$ or LPS (THP-1 cells) were added for $3 \mathrm{~h}$. Measurement of luciferase activity was performed using the Nano-Glo ${ }^{\circledR}$ Luciferase Assay system (Promega, Mannheim, Germany) according to the manufacturers' instructions.

\section{Western blot analysis}

HEK 293 cells were seeded in 12-well plates and allowed to grow to a confluency of $80-90 \%$ in full-growth medium. Before incubation, the medium was changed to serum-free medium. Cells were incubated with $240 \mu \mathrm{g} /$ $\mathrm{ml} \mathrm{EA} 575^{\circledR}$ for $8 \mathrm{~h}$ and with $25 \mathrm{ng} / \mathrm{ml} \mathrm{TNF} \alpha$ for $10 \mathrm{~min}$. After the incubation, cells were harvested with $100 \mu$ per well $10 \mathrm{mM}$ HEPES buffer containing phosphatase inhibitor cocktail (Merck, Darmstadt, Germany) and protease inhibitor cocktail (Sigma-Aldrich, Darmstadt, Germany). Cell solutions were sonified for $15 \mathrm{~s}$ and lysed by being forced through a $30 \mathrm{G}$ cannula. To separate cell debris, the solution was centrifuged at $15,000 \mathrm{~g}$ for $5 \mathrm{~min}$ at $4{ }^{\circ} \mathrm{C}$. Supernatant was diluted in $4 \times$ sample buffer and $20 \mu \mathrm{l}$ of the samples was separated in a $10 \%$ acrylamide gel with $80 \mathrm{~V}$ in stacking and $120 \mathrm{~V}$ in resolving gel. Blotting was done with $200 \mathrm{~mA}$ per gel for $45 \mathrm{~min}$. For normalization the membrane was stained after blotting with REVERT ${ }^{\text {TM }}$ total protein stain according to the manufacturers' instructions (LI-COR ${ }^{\circledR}$ ). Intensity was measured on an LI-COR ${ }^{\circledR}$ 
Odyssey reader in $700 \mathrm{~nm}$ channel. Afterwards, the stain was removed and membrane was blocked with Odyssey blocking buffer for $1 \mathrm{~h}$. Immunostaining was performed using phospho-IкBa antibody (Cells Signaling Technology, \#9246) or phospho-RelA antibody (Cell Signaling Technology, \#3033), respectively, in a dilution of 1:1000 in Odyssey blocking buffer diluted 1:1 with TBS and $0.1 \%$ Tween 20 . Afterwards, membrane was washed three times in TBS/Tween 20 and incubated in secondary antibody (LI-COR ${ }^{\circledR}$ Goat anti Rabbit-DyLight $800,1: 10,000$ ) diluted in Odyssey blocking buffer $1: 1$ with TBS, $0.1 \%$ Tween 20 and $0.01 \%$ SDS for $1 \mathrm{~h}$. Membrane was washed three times in TBS and measured on an LI-COR ${ }^{\circledR}$ Odyssey Reader in $800 \mathrm{~nm}$ channel. Protein concentration was normalized through the band intensity $\mathrm{pI \kappa B} \alpha / \mathrm{p}-\mathrm{RelA}$ divided by the normalization factor of REVERT ${ }^{\mathrm{TM}}$ total protein stain.

\section{Protein fragment complementation assay}

HEK cells stably expressing I $\kappa \mathrm{B} \alpha-n$ Venus and cVenusRelA were seeded into a black 96-well Plate (CellCarrier $^{\mathrm{TM}}$, Perkin Elmer, Massachusetts, USA) in total growth medium and allowed to grow to a confluency of about $90 \%$. After reaching confluency, medium was changed to HBSS buffer containing $20 \mathrm{mM}$ HEPES and was preincubated with the indicated concentration of EA $575^{\circledR}$ for $5 \mathrm{~h}$. Afterwards, cells were stimulated with $10 \mathrm{ng} / \mathrm{ml}$ $\mathrm{TNF} \alpha$ and decrease of fluorescence intensity was measured for $3 \mathrm{~h}$ every $60 \mathrm{~min}$ in a Perkin Elmer EnSight ${ }^{\mathrm{TM}}$ reader with excitation at $515 \mathrm{~nm}$ and emission at $550 \mathrm{~nm}$. Additionally, cell confluency was measured in transmission channel. Data were registered and evaluated by Kaleido $^{\mathrm{TM}}$ software.

\section{Statistical data evaluation}

Statistical data evaluation was performed with One-way ANOVA followed by Tukey multiple comparison test. Results were considered to be significant for $p$ values of at least $<0.05$.

\section{Results}

\section{EA $575^{\circ}$ analysis by HPLC}

Composition of EA $575^{\circledR}$ (DER 5-7.5:1, 30\% ethanol) was characterized by HPLC fingerprint analysis. The following substances could be identified by comparison of UV spectra and retention times of corresponding reference substances: rutin, hederacoside $\mathrm{C}$, hederacoside $\mathrm{D}$, and $\alpha$-hederin (Fig. 1).

\section{Partial inhibition of NFKB translocation into the nucleus}

As previously shown, pre-incubation with EA $575{ }^{\circledR}$ reduces IL-6 secretion from murine macrophage cell line J774.2 (Schulte-Michels et al. 2016a). To examine whether this reduction is achieved by an inhibition of nuclear translocation of $\mathrm{NF \kappa B}$, we performed an immunofluorescence assay on NFKB subunit RelA in J774.2 cells. Incubation with $25 \mathrm{ng} / \mathrm{ml} \mathrm{TNF} \alpha$ for 50 min showed a considerable shift of $\mathrm{NF \kappa B}$ (detected by $\mathrm{Cy} 3$ conjugated secondary antibody fluorescence) from cytosol to the nucleus (Fig. 2b) when compared to cells only incubated in serum-free medium (Fig. 2a). Overnight pre-incubation with $80 \mu \mathrm{g} / \mathrm{ml}$ EA $575^{\circledR}$ observably reduced the signal located in the nucleus after 50 min of stimulation (Fig. 2c). In parallel, nuclear translocation of NFKB was examined in human embryonic kidney
Fig. 1 HPLC fingerprint analysis of EA $575^{\circledR}$. Ingredients of the ivy leaves dry extract were separated on an RP-18 column. Main components were identified by comparison to retention times and absorbance of reference standards. The substances identified are rutin, hederacoside $\mathrm{C}$, hederacoside $\mathrm{D}$, and $\alpha$-hederin

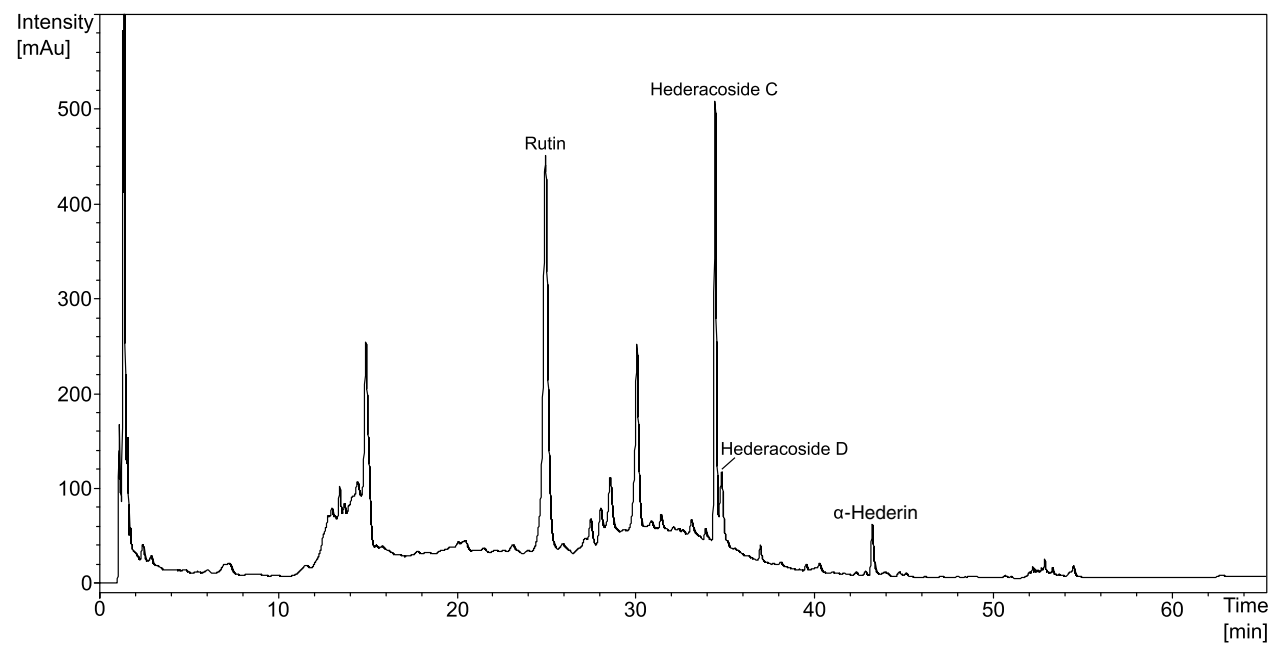



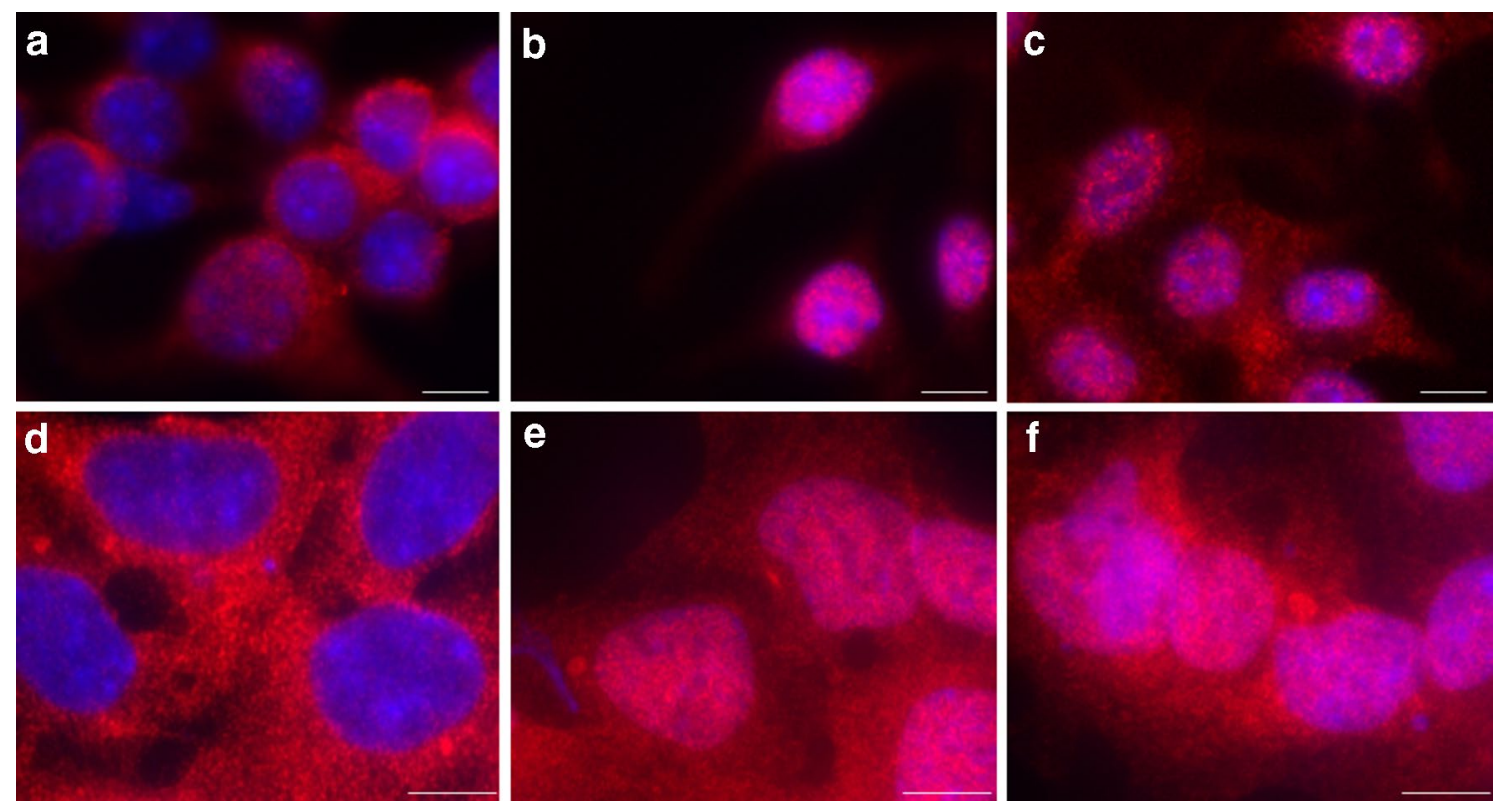

Fig. 2 NFאB immunostained in red with anti-RelA primary antibody and Cy3 coupled secondary antibody shown in J774.2 (a-c) as well as HEK 293 cells $(\mathbf{d}-\mathbf{f})$. Nucleus stained in blue with Hoechst 33258. $(\mathbf{a}+\mathbf{d})$ unstimulated cells, $(\mathbf{b}+\mathbf{e})$ cells stimulated with $100 \mathrm{ng} / \mathrm{ml}$ LPS (J774.2) or $25 \mathrm{ng} / \mathrm{ml}$ TNF $\alpha$ (HEK293) for $50 \mathrm{~min}$, and $(\mathbf{c}+\mathbf{f})$

epithelial cells (HEK 293; Fig. 2d-f). Reduction of translocation was also detected in these cells, even though the effect was not as pronounced as in the macrophage cell line.

\section{Nanoluciferase based NFKB reporter assay}

As shown previously by El-Guendy and colleagues, NFkB transcriptional activity can be measured by an NFKB reporter gene assay (El-Guendy and Sinai 2008). Stably transfected HEK 293 Nano-PEST cells showed an almost 25 -fold increase in Nanoluciferase activity after stimulation with $25 \mathrm{ng} / \mathrm{ml} \mathrm{TNF} \alpha$ for $3 \mathrm{~h}$. This increase could be significantly and dose-dependently decreased by $31.0,34.7$, and $42.1 \%$ after $8 \mathrm{~h}$ of pre-incubation with EA $575^{\circledR}$ concentrations of 40, 80, and $240 \mu \mathrm{g} / \mathrm{ml}$, respectively (Fig. 3).

\section{Western blot against phosphorylated ІкBa and RelA}

The disintegration of the NFKB:I $\kappa B \alpha$ complex is induced by the phosphorylation of I $\mathrm{B} \alpha \alpha$ mediated by IKK $\beta$, which also phosphorylates NFkB subunit RelA. Therefore, we measured both phosphorylation of I $\mathrm{K} \mathrm{\alpha}$ on Ser32 and phosphorylation of RelA at Ser536. Pre-incubation with $240 \mu \mathrm{g} / \mathrm{ml}$ EA $575^{\circledR}$ for $8 \mathrm{~h}$ was able to impede TNF $\alpha$-induced phosphorylation of IкB $\alpha$ on Ser32 significantly (Fig. 4). Phosphorylation of RelA at Ser536 was increased after pre-incubation with $240 \mu \mathrm{g} / \mathrm{ml}$ EA $575^{\circledR}$ and stimulation with TNF $\alpha$. A significant difference in RelA phosphorylation between ivy cells pre-incubated with $80 \mu \mathrm{g} / \mathrm{ml}(\mathrm{J} 774.2)$ or $240 \mu \mathrm{g} / \mathrm{ml}$ EA $575^{\circledR}$ (HEK293) overnight and subsequently stimulated with $100 \mathrm{ng} / \mathrm{ml}$ LPS (J774.2) or $25 \mathrm{ng} / \mathrm{ml} \mathrm{TNF \alpha} \mathrm{(HEK293)} \mathrm{for} 50 \mathrm{~min}$. Scale bars correspond to $10 \mu \mathrm{m}$. Shown pictures are representative of 3 independent experiments
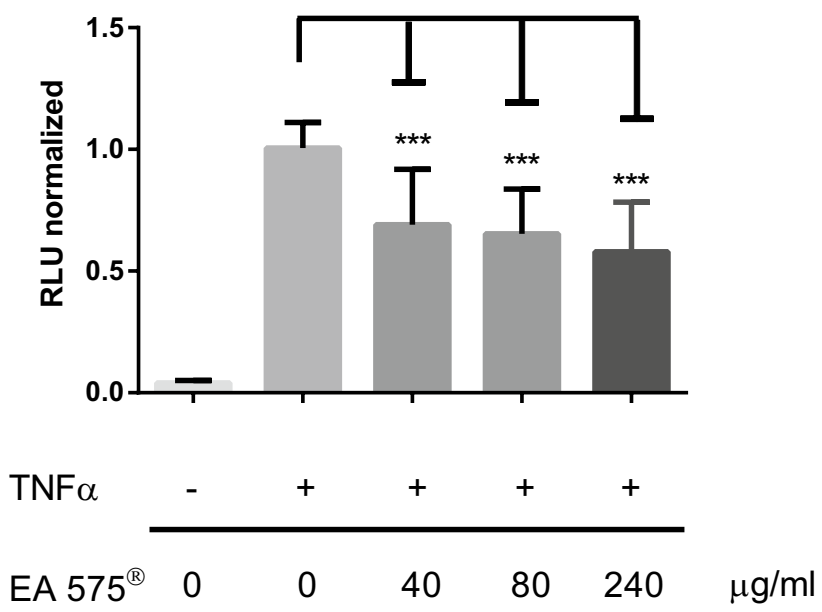

Fig. 3 HEK 293 cells stably transfected with a Nanoluciferase based NFKB reporter plasmid were incubated for $8 \mathrm{~h}$ with the indicated amounts of EA $575^{\circledR}$ or solvent alone. After $5 \mathrm{~h}$ of pre-incubation cells were stimulated for further $3 \mathrm{~h}$ with $25 \mathrm{ng} / \mathrm{ml} \mathrm{TNF} \alpha$ or left unstimulated. Results represent the mean $\pm \mathrm{SD}(n \geq 30, * * * p<0.001)$

pre-treated and control cells could be seen after $10 \mathrm{~min}$ of TNF $\alpha$ incubation (Fig. 5).

\section{Protein fragment complementation assay}

Reduced I $\mathrm{B} \alpha$ phosphorylation is thought to be a stabiliz-

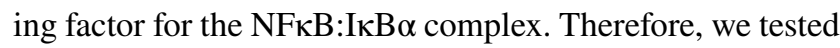



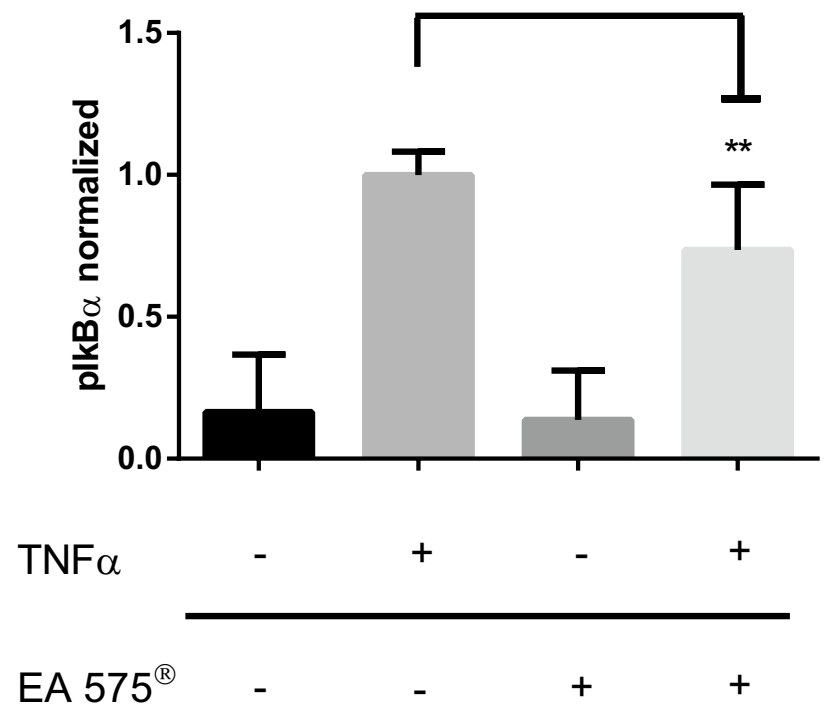

Fig. 4 Phosphorylation of $\mathrm{I} \kappa \mathrm{B} \alpha$ on Ser32 before and after stimulation with $25 \mathrm{ng} / \mathrm{ml} \mathrm{TNF} \alpha$ for $10 \mathrm{~min}$ and with or without pre-treatment with $240 \mu \mathrm{g} / \mathrm{ml}$ EA $575^{\circledR}$ for $8 \mathrm{~h}$. Results represent the mean $\pm \mathrm{SD}$ $(n \geq 8, * * p<0.01)$

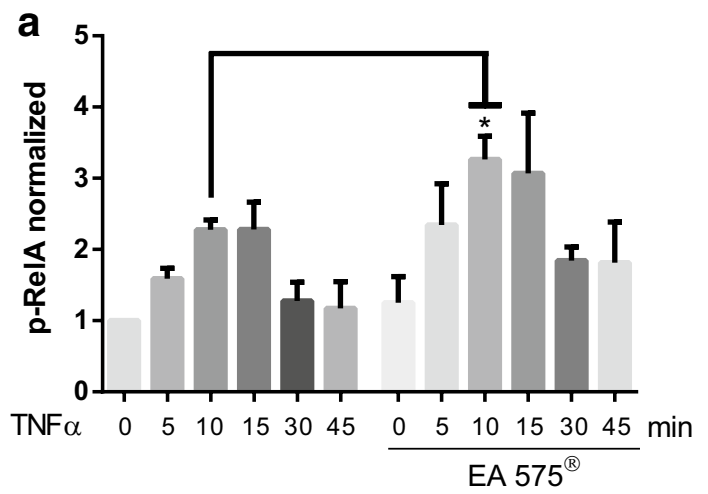

b

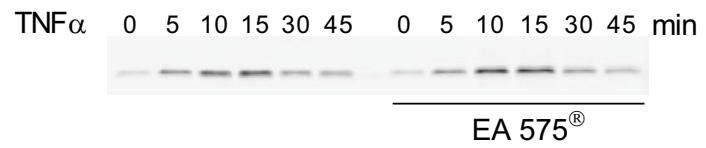

Fig. 5 Phosphorylation of RelA on Ser536 (p-RelA) in HEK cells after stimulation with $25 \mathrm{ng} / \mathrm{ml} \mathrm{TNF} \alpha$ for different time periods with or without pre-treatment using $240 \mu \mathrm{g} / \mathrm{ml}$ EA $575^{\circledR}$. a Quantitative analysis of western blot analysis. Results represent the mean \pm SD $\left(n \geq 3,{ }^{*} p<0.05\right)$. b Representative result of Western Blot analysis of p-RelA

via a protein fragment complementation assay if pre-incubation with EA $575^{\circledR}$ enhances the stability of NFkB:IкB $\alpha$ under TNF $\alpha$ stimulating conditions. In this assay, binding of $\mathrm{I} \kappa \mathrm{B} \alpha$ to NFKB results in the complementation of the fluorescent protein Venus. Disintegration of the complex in turn leads to a reduction of the detected Venus fluorescence
(Yu et al. 2003). As shown in Fig. 6, fluorescence intensity decreased by $47.4 \%$ after stimulation with $10 \mathrm{ng} / \mathrm{ml} \mathrm{TNF} \alpha$ for $3 \mathrm{~h}$. After pre-incubation with $160 \mu \mathrm{g} / \mathrm{ml} \mathrm{EA} 575^{\circledR}$ for $8 \mathrm{~h}, \mathrm{TNF} \alpha$-induced fluorescence intensity was lowered to $60.8 \%$, which represents $8.2 \%$ of conserved complex.

\section{Effects of EA $575^{\circ}$ on different cell types}

To further evaluate the observed regulatory effect of EA $575^{\circledR}$, we tested THP-1 as a human monocytic cell line, as well as A549 cells derived from human lung epithelium. Cells were stably transfected with the Nanoluciferase-based NFKB reporter. As can be seen in Fig. 7, both cell types showed increased Nanoluciferase levels after application of $\mathrm{TNF} \alpha$, which is significantly reduced when cells were preincubated with $240 \mu \mathrm{g} / \mathrm{ml}$ EA $575^{\circledR}$. Compared to cells incubated with TNF $\alpha$ only, inflammatory response was reduced to 75 and $88 \%$ for THP-1 and A549 cells, respectively.

\section{Discussion}

Ivy leaves dry extract EA $575^{\circledR}$ is well established for the improvement of symptoms associated with chronic inflammatory bronchial diseases, as well as for the treatment of acute inflammatory respiratory tract infections accompanied by coughing. Molecular mechanisms behind this anti-inflammatory activity of EA $575^{\circledR}$ have not yet been investigated satisfactorily.

EA $5755^{\circledR}$ reduces the amount of secreted IL- 6 from mouse macrophages (Schulte-Michels et al. 2016a). As can be derived from our work, this reduction is achieved via an

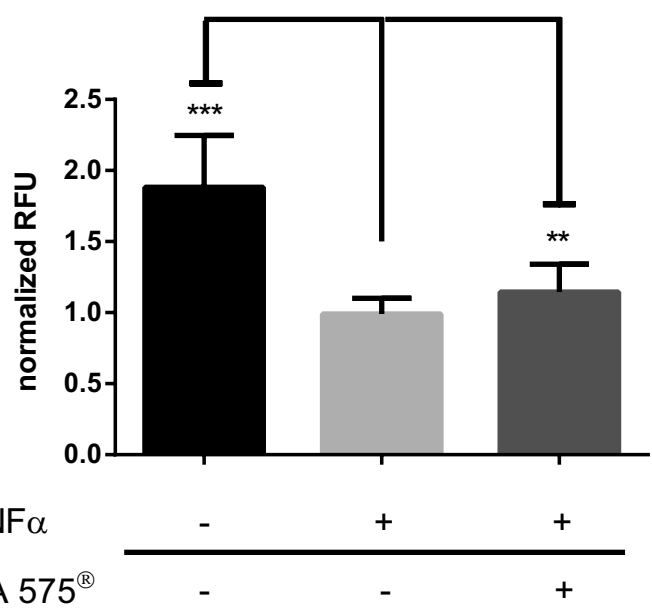

Fig. 6 Fluorescence intensity measurement of HEK 293 cells stably transfected with cVenus-RelA and I $\mathrm{KB} \alpha-n$ Venus before and after stimulation with $10 \mathrm{ng} / \mathrm{ml} \mathrm{TNF} \alpha$ and with or without pre-treatment using $160 \mu \mathrm{g} / \mathrm{ml}$ EA $575^{\circledR}$ for $8 \mathrm{~h}$. Results represent the mean \pm SD $(n$ $\geq 23, * * p<0.01, * * * p<0.001)$ 


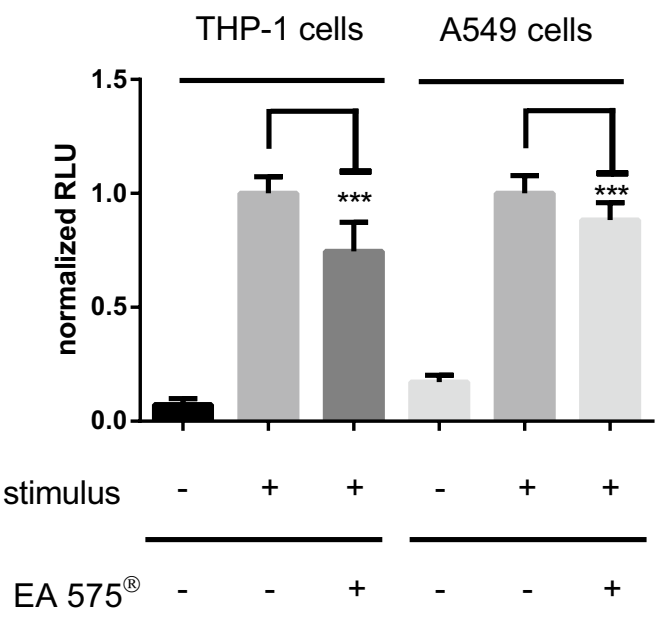

Fig. 7 NFאB activity in THP-1 and A549 Nano-PEST cells after stimulation with $10 \mathrm{ng} / \mathrm{ml}$ LPS or $5 \mathrm{ng} / \mathrm{ml} \mathrm{TNF} \alpha$, respectively, and with or without pre-treatment using $240 \mu \mathrm{g} / \mathrm{ml}$ EA $575^{\circledR}$. Data are shown as mean $\pm \mathrm{SD}$ of three independent experiments $(n \geq 16$, $* * * p<0.001)$

impaired nuclear translocation of NFKB, which we displayed by an immunofluorescence assay against RelA, a subunit

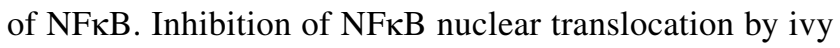
leaves constituents, e.g., rutin as well as chlorogenic and dicaffeoylquinic acids, was already shown in mast cells and macrophages (Kim et al. 2008; Puangpraphant et al. 2011; Hwang et al. 2014). Using an NFאB reporter gene assay, we could show that EA $575^{\circledR}$ inhibits dose-dependently the tran-

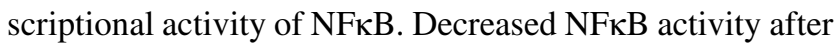
administration of ivy constituents was already shown. For example, rutin as well as 3,5- and 4,5-dicaffeoylquinic acid inhibits the NFKB-dependent iNOS gene transcription, and as a result the synthesis of nitric oxide, whereas chlorogenic acid reduces LPS-induced NFKB-dependent cyclooxygenase-2 (COX-2) expression in RAW 264.7 cells (Shan et al. 2009; Park et al. 2009; Kazłowska et al. 2010). Furthermore, 3,4-dicaffeoylquinic acid inhibits the phorbol-12-myristate13-acetate-induced COX-2 expression in RAW264.7 cells by blocking the catalytic activity of JNK/p38 MAP kinases and the activation of C/EBP $\beta$ and AP-1 (Han et al. 2010). The impairment of nuclear translocation and reduction in transcriptional activity of NFKB might be caused by an enhanced

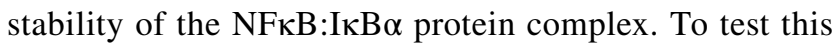
issue, we performed a protein fragment complementation assay where Venus protein fluorescence is achieved upon binding of $\mathrm{I} \kappa \mathrm{B} \alpha$ to $\mathrm{NF} \kappa \mathrm{B}$. After stimulation with $10 \mathrm{ng} /$ $\mathrm{ml} \mathrm{TNF} \alpha$, preserved Venus fluorescence was significantly higher when cells were pre-incubated with EA $575^{\circledR}$, thereby demonstrating an enhanced stability under TNF $\alpha$ stimulation. Complex stability is regulated by phosphorylation of I $\mathrm{B} \alpha$ through IKK $\beta$, which forms together with IKK $\alpha$ and their regulating subunit IKK $\gamma$ (also called NEMO) the IKK complex. Phosphorylation of $\mathrm{I} \kappa \mathrm{B} \alpha$ on serine at position 32 (Ser32) leads to its ubiquitination and proteasomal degradation and thereby the release of NFKB from the complex, permitting it to translocate into the nucleus (Scheidereit 2006). Thus, we were interested in whether the observed effects were due to reduced phosphorylation of $\operatorname{I\kappa B} \alpha$. A Western blot against $\mathrm{I} \kappa \mathrm{B} \alpha$ phosphorylated at Ser32 indicated a reduced phosphorylation at this site, which explains

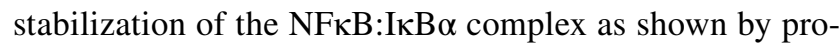
tein fragment complementation (see above). Reduced cellular phosphorylation of I $\mathrm{B} \alpha$ after incubation with natural products also existing in EA $575^{\circledR}$ was already demonstrated, as for chlorogenic acid on hepatic stellate cells (Shi et al.

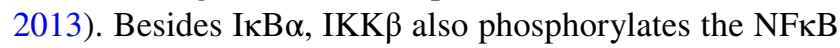
subunit RelA at Ser536. Indeed, we also found an impact on RelA-Ser536 phosphorylation which was increased after pre-incubation of cells with EA $575^{\circledR}$. The phosphorylation of RelA is much less understood. Besides several phosphorylation sites which seem to have positive effects on RelA transcriptional activity, there is increasing evidence that the phosphorylation of Ser536 by IKK $\beta$ impairs the nuclear translocation of RelA and thereby diminishes its transcriptional activity (Mattioli et al. 2004; Moreno et al. 2010; Christian et al. 2016). Schröfelbauer et al. showed that the phosphorylation of $\mathrm{I} \kappa \mathrm{B} \alpha$ on Ser32 depends on the scaffold function of NEMO and that inhibition of NEMO leads to a switch in its specificity towards RelA at Ser536, which is in good accordance with our observations (Schröfelbauer et al. 2012).

In addition to factors secreted by immune cells, those released by epithelial cells also promote inflammation of lung tissue (Mitchell and O'Byrne 2016, 2017; Green and Turner 2017). Consistent with that, the anti-inflammatory effect of EA $575^{\circledR}$, detected in monocytes/macrophages (THP-1/J774.2) and examined here in detail in HEK cells, can also be observed in A 549 cells, a human lung epithelial cell. The precise target cells of EA $575^{\circledR}$ in the inflamed lung should be the subject of future studies.

Taken together, our results indicate that the previously shown anti-inflammatory properties of EA $575^{\circledR}$ (SchulteMichels et al. 2016a) result from a regulatory effect on the $\mathrm{NF \kappa B}$ pathway, which is probably due to a specificity switch of IKK $\beta$. As discussed above, this would reduce RelA transcriptional activity in a duplexed manner, firstly by stabilizing the complex with its inhibitor and secondly by reducing RelA translocation into the nucleus. Whether EA $575^{\circledR}$ achieves this by manipulating the scaffold function of the regulatory NEMO subunit, leading to stronger association of IKK $\beta$ to RelA compared to I $\kappa \mathrm{B} \alpha$, must be subject of further investigations.

Acknowledgements This work was supported by a research grant of Engelhard Arzneimittel GmbH \& Co.KG, Niederdorfelden, Germany. 


\section{Compliance with ethical standards}

Conflict of interest S Franken is an employee of Engelhard Arzneimittel GmbH \& Co.KG, Niederdorfelden, Germany. All other authors confirm that there is no conflict of interest.

Open Access This article is distributed under the terms of the Creative Commons Attribution 4.0 International License (http://creativeco mmons.org/licenses/by/4.0/), which permits unrestricted use, distribution, and reproduction in any medium, provided you give appropriate credit to the original author(s) and the source, provide a link to the Creative Commons license, and indicate if changes were made.

\section{References}

Christian F, Smith EL, Carmody RJ (2016) The regulation of NF-кB subunits by phosphorylation. Cells. https://doi.org/10.3390/cells 5010012

dos Santos MD, Almeida MC, Lopes NP, de Souza GEP (2006) Evaluation of the anti-inflammatory, analgesic and antipyretic activities of the natural polyphenol chlorogenic acid. Biol Pharm Bull 29:2236-2240. https://doi.org/10.1248/bpb.29.2236

El-Guendy N, Sinai AP (2008) Potential problems inherent in cellbased stable NF-kappaB-GFP reporter systems. Mol Cell Biochem 312:147-155. https://doi.org/10.1007/s11010-008-9730-8

Green CE, Turner AM (2017) The role of the endothelium in asthma and chronic obstructive pulmonary disease (COPD). Respir Res 18:20. https://doi.org/10.1186/s12931-017-0505-1

Greunke C, Hage-Hülsmann A, Sorkalla T et al (2015) A systematic study on the influence of the main ingredients of an ivy leaves dry extract on the $\beta 2$-adrenergic responsiveness of human airway smooth muscle cells. Pulm Pharmacol Ther 31:92-98. https://doi. org/10.1016/j.pupt.2014.09.002

Guardia T, Rotelli AE, Juarez AO, Pelzer LE (2001) Anti-inflammatory properties of plant flavonoids. Effects of rutin, quercetin and hesperidin on adjuvant arthritis in rat. Farmaco 56:683-687

Han EH, Kim JY, Kim HG et al (2010) Inhibitory effect of 3-caffeoyl4-dicaffeoylquinic acid from Salicornia herbacea against phorbol ester-induced cyclooxygenase-2 expression in macrophages. Chem Biol Interact 183:397-404. https://doi.org/10.1016/j. cbi.2009.11.015

Hayden MS, Ghosh S (2012) NF-kB, the first quarter-century: remarkable progress and outstanding questions. Genes Dev 26:203-234. https://doi.org/10.1101/gad.183434.111

Hocaoglu AB, Karaman O, Erge DO et al (2012) Effect of Hedera helix on lung histopathology in chronic asthma. Iran J Allergy Asthma Immunol 11:316-323

Hwang SJ, Kim Y-W, Park Y et al (2014) Anti-inflammatory effects of chlorogenic acid in lipopolysaccharide-stimulated RAW 264.7 cells. Inflamm Res 63:81-90. https://doi.org/10.1007/s0001 1-013-0674-4

Kazłowska K, Hsu T, Hou C-C et al (2010) Anti-inflammatory properties of phenolic compounds and crude extract from Porphyra dentata. J Ethnopharmacol 128:123-130. https://doi.org/10.1016/j. jep.2009.12.037

Kim HP, Park H, Son KH et al (2008) Biochemical pharmacology of biflavonoids: implications for anti-inflammatory action. Arch Pharm Res 31:265-273. https://doi.org/10.1007/s1227 2-001-1151-3

Kim H-R, Lee D-M, Lee S-H et al (2010) Chlorogenic acid suppresses pulmonary eosinophilia, IgE production, and Th2-type cytokine production in an ovalbumin-induced allergic asthma: activation of STAT-6 and JNK is inhibited by chlorogenic acid.
Int Immunopharmacol 10:1242-1248. https://doi.org/10.1016/j. intimp.2010.07.005

Lang C, Rottger-Luer P, Staiger C (2015) A valuable option for the treatment of respiratory diseases: review on the clinical evidence of the Ivy Leaves Dry Extract EA 575(R). Planta Med 81:968974. https://doi.org/10.1055/s-0035-1545879

Mattioli I, Sebald A, Bucher C et al (2004) Transient and selective NF-kappa B p65 serine 536 phosphorylation induced by T cell costimulation is mediated by I kappa B kinase beta and controls the kinetics of p65 nuclear import. J Immunol 172:6336-6344

Mitchell PD, O'Byrne PM (2016) Epithelial derived cytokines in asthma. Chest. https://doi.org/10.1016/j.chest.2016.10.042

Mitchell PD, O'Byrne PM (2017) Biologics and the lung: TSLP and other epithelial cell-derived cytokines in asthma. Pharmacol Ther 169:104-112. https://doi.org/10.1016/j.pharmthera.2016.06.009

Moreno R, Sobotzik J-M, Schultz C, Schmitz ML (2010) Specification of the NF-kappaB transcriptional response by p65 phosphorylation and TNF-induced nuclear translocation of IKK epsilon. Nucleic Acids Res 38:6029-6044. https://doi.org/10.1093/nar/ gkq439

Park KH, Park M, Choi SE et al (2009) The anti-oxidative and antiinflammatory effects of caffeoyl derivatives from the roots of Aconitum koreanum R. RAYMOND. Biol Pharm Bull 32:2029-2033

Puangpraphant S, Berhow MA, Vermillion K et al (2011) Dicaffeoylquinic acids in Yerba mate (Ilex paraguariensis St. Hilaire) inhibit NF- $\mathrm{KB}$ nucleus translocation in macrophages and induce apoptosis by activating caspases- 8 and -3 in human colon cancer cells. Mol Nutr Food Res 55:1509-1522. https://doi. org/10.1002/mnfr.201100128

Scheidereit C (2006) IkappaB kinase complexes: gateways to NF-kap$\mathrm{paB}$ activation and transcription. Oncogene 25:6685-6705. https ://doi.org/10.1038/sj.onc.1209934

Schröfelbauer B, Polley S, Behar M et al (2012) NEMO ensures signaling specificity of the pleiotropic IKK $\beta$ by directing its kinase activity toward IкB $\alpha$. Mol Cell 47:111-121. https://doi. org/10.1016/j.molcel.2012.04.020

Schulte-Michels J, Runkel F, Gokorsch S, Häberlein H (2016a) Ivy leaves dry extract EA $575^{\circledR}$ decreases LPS-induced IL-6 release from murine macrophages. Pharmazie 71:158-161

Schulte-Michels J, Wolf A, Aatz S et al (2016b) $\alpha$-Hederin inhibits $\mathrm{G}$ protein-coupled receptor kinase 2-mediated phosphorylation of $\beta 2$-adrenergic receptors. Phytomedicine 23:52-57. https://doi. org/10.1016/j.phymed.2015.12.001

Selloum L, Bouriche H, Tigrine C, Boudoukha C (2003) Anti-inflammatory effect of rutin on rat paw oedema, and on neutrophils chemotaxis and degranulation. Exp Toxicol Pathol 54:313-318. https://doi.org/10.1078/0940-2993-00260

Shan J, Fu J, Zhao Z et al (2009) Chlorogenic acid inhibits lipopolysaccharide-induced cyclooxygenase- 2 expression in RAW264.7 cells through suppressing NF-kappaB and JNK/AP-1 activation. Int Immunopharmacol 9:1042-1048. https://doi.org/10.1016/j. intimp.2009.04.011

Shi H, Dong L, Dang X et al (2013) Effect of chlorogenic acid on LPS-induced proinflammatory signaling in hepatic stellate cells. Inflamm Res 62:581-587. https://doi.org/10.1007/s0001 1-013-0610-7

Sieben A, Prenner L, Sorkalla T et al (2009) Alpha-hederin, but not hederacoside $\mathrm{C}$ and hederagenin from Hedera helix, affects the binding behavior, dynamics, and regulation of beta 2-adrenergic receptors. Biochemistry 48:3477-3482. https://doi.org/10.1021/ bi802036b

Süleyman H, Mshvildadze V, Gepdiremen A, Elias R (2003) Acute and chronic antiinflammatory profile of the ivy plant, Hedera helix, in rats. Phytomedicine 10:370-374. https://doi. org/10.1078/0944-7113-00260 
Yu H, West M, Keon BH et al (2003) Measuring drug action in the cellular context using protein-fragment complementation assays. Assay Drug Dev Technol 1:811-822. https://doi. org/10.1089/154065803772613444
Zhang X, Huang H, Yang T et al (2010) Chlorogenic acid protects mice against lipopolysaccharide-induced acute lung injury. Injury 41:746-752. https://doi.org/10.1016/j.injury.2010.02.029 